\title{
Endothelin-A Receptor Blockade and Inhaled Nitric Oxide in a Porcine Model of Meconium Aspiration Syndrome
}

\author{
LARA S. SHEKERDEMIAN, DANIEL J. PENNY, PIA K. RYHAMMER, JAYNE A. READER, AND \\ HANNE B. RAVN \\ Paediatric Intensive Care Unit [L.S.S.], Department of Cardiology [D.J.P.], Royal Children's Hospital, \\ Parkville, Victoria 3052, Australia, Department of Anaesthesia and Intensive Care [P.K.R., H.B.R.], and \\ Institute of Experimental Research, University of Aarhus, 8200-Aarhus, Denmark, and Department of \\ Vascular Biology [J.A.R.], Institute of Child Health, London WC1, England
}

\begin{abstract}
ABSTR
Acute neonatal pulmonary hypertension is associated with
increased activation of the endogenous endothelin pathway. We
investigated the role of selective endothelin-A receptor blockade
using i.v. BQ-123 in a piglet model of meconium aspiration
syndrome. Meconium aspiration was induced in 18 anesthetized
piglets. Six controls received no further intervention. Six piglets
received 1 mg/kg BQ-123 at 120 min, with the addition of 20
ppm inhaled nitric oxide at 240 min. Six commenced nitric oxide
therapy at 120 min, and were given i.v. BQ-123 at 240 min. The
total study duration was 360 min. Meconium aspiration resulted
in acute pulmonary hypertension and elevated endothelin-1 lev-
els in all animals. There were no changes in pulmonary hemo-
dynamics or endothelin-1 levels beyond 120 min in controls. In
the group receiving BQ-123 first, this agent alone reduced the
pulmonary artery pressure and pulmonary vascular resistance,
\end{abstract}
PPHN occurs when there is a failure of the normal rapid fall in PVR and increase in pulmonary blood flow with the onset of respiration at birth (1). Meconium aspiration syndrome is the single most common cause of PPHN, and can result in significant morbidity and mortality in term and near-term infants (2).

The normal transition from the high-resistance fetal circulation to the low-resistance postnatal pulmonary circulation is associated with activation of the endogenous vasodilator nitric oxide-cyclic guanosine 5'-monophosphate pathway, and reduced release of the potent pulmonary vasoconstrictor, ET (3). The ET-1 isopeptide is a 21-amino acid polypeptide (4) that is produced within the pulmonary endothelium by the cleavage of its precursor, pro-ET (big ET), by ET converting enzyme. ET-1 is released by the vascular endothelium, and produces its

Received September 2, 2003; accepted February 10, 2004.

Correspondence: Lara Shekerdemian, M.D., Paediatric Intensive Care Unit, Royal Children's Hospital, Flemington Rd., Parkville, Melbourne, Victoria 3052, Australia; e-mail: lara.shekerdemian@rch.org.au

Supported by a grant from the Institute of Child Health, London, England.

DOI: 10.1203/01.PDR.0000134257.20214.57 and the subsequent addition of inhaled nitric oxide further reduced pulmonary artery pressure. In the group first receiving nitric oxide alone, this reduced the pulmonary artery pressure, and the addition of BQ-123 resulted in a fall in pulmonary vascular resistance. Endothelin-1 levels increased with both agents. BQ-123 was found to be a highly effective pulmonary vasodilator and augmented the effects of nitric oxide in this model of acute pulmonary hypertension. (Pediatr Res 56: 353$358,2004)$
Abbreviations
PPHN, persistent pulmonary hypertension of the newborn
PVR, pulmonary vascular resistance
ET, endothelin
iNO, inhaled nitric oxide

effects through its interaction with at least two receptor subtypes - the A and B receptors, located on the vascular smooth muscle and endothelium. The pulmonary vasoconstrictor effects of ET-1 result mainly from activation of the G-proteincoupled smooth muscle A receptor, whereas stimulation of the endothelial ET-B receptor has been shown to result in vasodilatation (5). ET-1 is present in high levels at birth, with a gradual fall during the early neonatal period in healthy individuals (6). Elevated ET-1 levels have been demonstrated in animal models of meconium aspiration (7), in neonates with PPHN (3, 8, 9), and in older children (10) and adults (11) with pulmonary hypertension. Furthermore, the plasma ET-1 level appears to positively correlate with disease severity $(8,9,12)$.

Therapy for pulmonary hypertension in the neonate is currently targeted at preventing or reversing the sequelae of pulmonary endothelial dysfunction. iNO improves oxygenation and reduces the need for extracorporeal life support in some of the most severe cases (13). However, the individual response to iNO is disease specific $(13,14)$. In infants with meconium aspiration syndrome, the distribution of iNO, and its 
subsequent efficacy, can be limited by the presence of meconium in the airways, reduced surfactant activity, and widespread ventilation-perfusion mismatch (14). There is a need for continued investigation of adjuncts, or even alternatives to $\mathrm{iNO}$, and in particular exploration of the role of systemic agents for the treatment of acute pulmonary hypertension.

We recently demonstrated an acute fall in PVR, in response to an i.v. bolus of the selective ET-A receptor antagonist BQ-123, in children after surgery for congenital heart disease (15). Acute, selective ET-A receptor blockade has been shown to reduce PVR in piglet and lamb models of hypoxic pulmonary hypertension (16-18) and congenital diaphragmatic hernia (19). Previous investigators have suggested that ET-A receptor blockade may improve smooth muscle responsiveness to iNO in monocrotaline-induced pulmonary hypertension (20), and it has recently been proposed that ET-A receptor antagonists may have a role in the prevention of rebound pulmonary hypertension upon iNO withdrawal (21).

In this study, we have compared for the first time the pulmonary vascular responses to the selective i.v. ET-A receptor antagonist BQ-123 and iNO, and have examined the acute interaction between the two agents in a piglet model of acute pulmonary hypertension secondary to meconium aspiration syndrome.

\section{METHODS}

The study conformed to the U.S. Guide for the Care and Use of Laboratory Animals (National Institutes of Health Publication No 85-23, revised 1996). Eighteen female Danish Landrace piglets weighing $4.9 \mathrm{~kg}$ were premedicated with intramuscular ketamine $(2 \mathrm{mg} / \mathrm{kg})$ and midazolam $(1 \mathrm{mg} / \mathrm{kg})$, followed by an i.v. bolus of ketamine $(1 \mathrm{mg} / \mathrm{kg})$ administered through the ear vein. They were anesthetized, ventilated, instrumented for monitoring of systemic blood pressure, pulmonary artery pressure, and cardiac output, and sedated, as previously described (22).

After completing the preparation, hemodynamics were allowed to stabilize for $15 \mathrm{~min}$. Then systemic, central venous, pulmonary arterial, and pulmonary capillary wedge pressures, ventilatory settings, and cardiac output were recorded and an arterial blood gas was taken. Systemic and pulmonary vascular resistances and oxygenation index were calculated using standard equations. Inspired oxygen and tidal volumes were adjusted to maintain an arterial $\mathrm{Po}_{2}$ of $70-100 \mathrm{~mm} \mathrm{Hg}$, and carbon dioxide of $35-45 \mathrm{~mm} \mathrm{Hg}$. After $30 \mathrm{~min}$, a further set of hemodynamics was recorded, and blood gas analysis was performed; these measurements were taken as baseline $(0 \mathrm{~min})$.

Each animal then received a deep intratracheal instillation (3 $\mathrm{mL} / \mathrm{kg}$ ) of a $20 \%$ solution of pooled human meconium, prepared as previously described (22). Animals were randomly allocated to one of three study groups. Six animals (controls) did not receive any further therapeutic intervention, and were monitored for $360 \mathrm{~min}$. Six animals received a single dose (1 $\mathrm{mg} / \mathrm{kg}$ infused over $20 \mathrm{~min}$ ) of i.v. BQ-123 (Clinalfa AG, Laufelfingen, Switzerland) at $120 \mathrm{~min}$ and were given iNO (20 ppm) at $240 \mathrm{~min}$. iNO was continued until the experiment was terminated at $360 \mathrm{~min}$. The six remaining animals received
iNO at $120 \mathrm{~min}$, with a dose of i.v. BQ-123 $(1 \mathrm{mg} / \mathrm{kg})$ at 240 $\min$.

An arterial blood gas was taken 30 min after each intervention, and complete sets of measurements (hemodynamics and blood gases) were made hourly. Ventilation was adjusted aiming to achieve the parameters outlined above. Systemic arterial samples were taken for ET-1 assays at 0, 120, 240, and $360 \mathrm{~min}$.

At the end of the study, all animals underwent fluoroscopy with an injection of i.v. contrast to the right atrium to exclude an intracardiac right-to-left shunt, and then were killed with a lethal injection of i.v. pentobarbital.

ET-1 assay. Blood samples were taken using EDTA as an anticoagulant, and were immediately centrifuged at $1000 \mathrm{~g}$ at $4^{\circ} \mathrm{C}$ for $10 \mathrm{~min}$, and the supernatant plasma was stored at $-40^{\circ} \mathrm{C}$. A quantitative sandwich ELISA technique (QuantiGlo human ET-1 assay, R \& D Systems, Minneapolis, MN, U.S.A,) was used to detect ET-1 (in picograms per milliliter). This assay has a coefficient of variation for repeated measurements of $2.5 \%$ within the range of $1-20 \mathrm{pg} / \mathrm{mL}$, with a minimum detectable ET-1 concentration of $0.16 \mathrm{pg} / \mathrm{mL}$ and a crossreactivity with big ET of $0.01-0.02 \%$. Samples were measured in duplicate and diluted both 1:1 and 1:10, and were pipetted into microplate wells precoated with ET-1-specific MAb. After removing the unbound substance, the ELISA antibody was added to the wells, and light produced in response to the addition of luminol/peroxide substrate was measured with a microplate luminometer.

Statistics. Measurements in the three groups at each time point were compared with a one-way ANOVA. Within-group responses to interventions (meconium instillation, iNO, and BQ-123) were evaluated with a one-way repeated measures ANOVA, using Bonferroni's correction for multiple comparisons. Results are expressed as mean (SEM); a $p$ value of $<0.05$ was considered statistically significant.

\section{RESULTS}

\section{Meconium Instillation: 0-120 min}

Baseline recordings and initial changes in hemodynamic and oxygenation variables after meconium instillation (120 min) were similar for all three study groups; therefore the responses to meconium instillation between 0 and $120 \mathrm{~min}$ for the 18 animals will be considered together (Table 1).

Meconium instillation significantly increased the mean pulmonary artery pressure and PVR. Systemic hemodynamics and systemic vascular resistance were unchanged; thus, the ratio of pulmonary-to-systemic vascular resistance increased significantly. Meconium instillation necessitated an increase in inspired oxygen fraction and mean airway pressure to maintain the target level of oxygenation; thus, the oxygenation index more than doubled (mean increase $135 \pm 44 \%$ ). ET-1 levels also increased significantly after meconium instillation.

\section{Changes Occurring Between 120 and 360 min}

Changes occurring between 120 and 360 min are described in Table 2 and Figure 1. 
Table 1. Hemodynamic parameters for all animals $(\mathrm{n}=18) a t$ baseline (0 min) and $120 \mathrm{~min}$ after meconium instillation

\begin{tabular}{|c|c|c|c|c|}
\hline \multirow{3}{*}{$\begin{array}{l}\text { Parameter } \\
\text { Weight }(\mathrm{kg}) \\
\text { Cardiac output }(\mathrm{mL} / \mathrm{kg} / \mathrm{min})\end{array}$} & \multicolumn{2}{|c|}{$0 \mathrm{~min}$} & \multicolumn{2}{|c|}{$120 \mathrm{~min}$} \\
\hline & 4.9 & $(0.11)$ & - & - \\
\hline & 169 & (10) & 176 & $(10)$ \\
\hline Mean PAP (mm Hg) & 17.8 & $(0.7)$ & 24.4 & $(0.9)^{*}$ \\
\hline Mean PCWP (mm Hg) & 7.8 & $(0.6)$ & 7.1 & $(0.7)$ \\
\hline Mean ABP (mm Hg) & 59 & $(1.2)$ & 62 & (1.4) \\
\hline CVP (mm Hg) & 7.6 & $(0.6)$ & 7.3 & $(0.6)$ \\
\hline Mean PVR (units/kg) & 0.065 & $(0.005)$ & 0.106 & $(0.01)^{*}$ \\
\hline Mean SVR (units/kg) & 0.33 & $(0.02)$ & 0.33 & $(0.02)$ \\
\hline PVR/SVR & 0.20 & $(0.01)$ & 0.31 & $(0.02)^{*}$ \\
\hline Paw $\left(\mathrm{cm} \mathrm{H}_{2} \mathrm{O}\right)$ & 9.7 & $(0.3)$ & 12.1 & $(0.5)^{*}$ \\
\hline $\mathrm{PaO}_{2}(\mathrm{~mm} \mathrm{Hg})$ & 101 & (6) & 82 & $(6)^{*}$ \\
\hline Oxygenation index & 3.0 & $(0.2)$ & 6.1 & $(0.7)^{*}$ \\
\hline Endothelin-1 (pg/mL) & 1.52 & $(0.21)$ & 2.34 & $(0.31)^{*}$ \\
\hline
\end{tabular}

PAP, pulmonary artery pressure; PCWP, pulmonary capillary wedge pressure; ABP, arterial blood pressure; CVP, central venous pressure; PVR, pulmonary vascular resistance; SVR, systemic vascular resistance; Paw, mean airway pressure; $\mathrm{PaO}_{2}$, arterial partial pressure of oxygen.

$* p<0.05$.

Controls. In the six controls, there were no further significant changes in hemodynamic parameters, or in oxygenation index, for the remainder of the study period. ET-1 levels did not change significantly beyond $120 \mathrm{~min}$.

BQ-123 at $120 \mathrm{~min}$ with iNO at $240 \mathrm{~min}$. An infusion of BQ-123 alone significantly reduced pulmonary artery pressure, and tended to increase cardiac output ( $p=0.07)$. Pulmonary capillary wedge pressure was unchanged, and PVR fell significantly. Mean arterial blood pressure fell transiently between 120 and $180 \mathrm{~min}$, but increased again to pre-BQ levels at 240 min (Fig. 1); and systemic vascular resistance was unchanged. PVR and the pulmonary-to-systemic vascular resistance ratio were reduced significantly at $240 \mathrm{~min}$.

The addition of iNO to animals after BQ-123 produced significant falls in mean pulmonary artery and pulmonary capillary wedge pressures, but did not change cardiac output. PVR, systemic hemodynamics, ventilatory requirements, and oxygenation were unchanged by iNO.

Infusion of BQ-123 resulted in a significant increase in plasma ET-1 levels between 120 and $180 \mathrm{~min}$, and ET-1 increased further between 240 and 360 min during iNO therapy (Fig. 1).

iNO at $120 \mathrm{~min}$ with BQ-123 at $240 \mathrm{~min}$. $\mathrm{iNO}$ alone significantly reduced the pulmonary artery pressure. Cardiac output was unchanged, and PVR tended to fall between 120 and $240 \mathrm{~min}$, though this change did not quite reach statistical significance $(p=0.1)$. The addition of BQ-123 at $240 \mathrm{~min}$ tended to increase the cardiac output $(p=0.07)$, without producing any change in pulmonary capillary wedge pressure or pulmonary arterial pressure. PVR fell significantly between 240 and 360 min (Fig. 1). Mean systemic blood pressure fell transiently between 240 and $300 \mathrm{~min}$, but this change had reversed by $360 \mathrm{~min}$ (Fig. 1).

ET-1 levels were obtained from 16 animals. Samples were unsuitable from one control, and from one animal in the group receiving nitric oxide first. ET-1 increased significantly during iNO alone, and continued to increase after the addition of
BQ-123 (Fig. 1). Ventilatory requirements and oxygenation were unchanged by any of the therapeutic interventions.

At the conclusion of the study, none of the subjects had any evidence of an intracardiac shunt on contrast injection.

\section{DISCUSSION}

Our current study has clearly demonstrated that BQ- 123 is an effective and relatively selective pulmonary vasodilator in the treatment of pulmonary hypertension in this model of meconium aspiration syndrome. BQ-123 reduced the pulmonary artery pressure without changing wedge pressure, and tended to increase the cardiac output. When given to animals already receiving iNO, BQ-123 further lowered the PVR. There was a minimal $(<10 \%)$ and transient reduction in systemic blood pressure during the first hour after BQ-123 administration, which self-corrected without intervention. Neither agent produced any detectable effect upon oxygenation, either alone or in combination, in this group of animals without an intracardiac shunt.

Endothelial function is a key determinant of pulmonary vascular tone and development. In recent years, treatments for PPHN have been aimed at controlling or reversing the pulmonary endothelial dysfunction, which otherwise rapidly initiates the unrelenting cascade of pulmonary hypertension, right-toleft shunting, and hypoxemia. iNO has an important role in the acute management of pulmonary hypertension (14). However, the limited response in some patient groups, the potential for rebound upon iNO withdrawal, and more recent financial implications of long-term iNO therapy, coupled with our increasing understanding of other important molecular pathways in the pathophysiology of pulmonary hypertension, remain compelling stimuli for research into other agents $(23,24)$.

There are few clinical investigations of ET receptor blockade in the treatment of acute pulmonary hypertension in the literature to date. Two previous studies have demonstrated a preventive effect of ET-A receptor blockade on the subsequent development of pulmonary hypertension in an acute hypoxic rat model (25) and in a model of meconium aspiration (26). The beneficial effects of other ET-A receptor antagonists in the treatment of acute pulmonary hypertension have recently been demonstrated in lamb $(16,17)$, and pig (27) models of acute hypoxic pulmonary hypertension, and in a lamb model of congenital diaphragmatic hernia (19). Furthermore, the intravenous combined ET-A and -B receptor antagonist, tezosentan, has been shown to reduce PVR in a model of oleic acidinduced lung injury (28). There are no published studies that compare the clinical effects of ET-A receptor antagonists with iNO in acute pulmonary hypertension, and a single published study has examined the combined influences of ET-A receptor blockade and $\mathrm{iNO}$ in an acute hypoxic pulmonary hypertension. In this model, receptor blockade reduced PVR, and this fell further with the addition of iNO (29).

Our current study is therefore unique in a number of ways. First, we have explored for the first time the use of the ET-A receptor antagonist, BQ-123, as a treatment for pulmonary hypertension secondary to meconium aspiration. Second, we have compared the agent with iNO, which is the current 


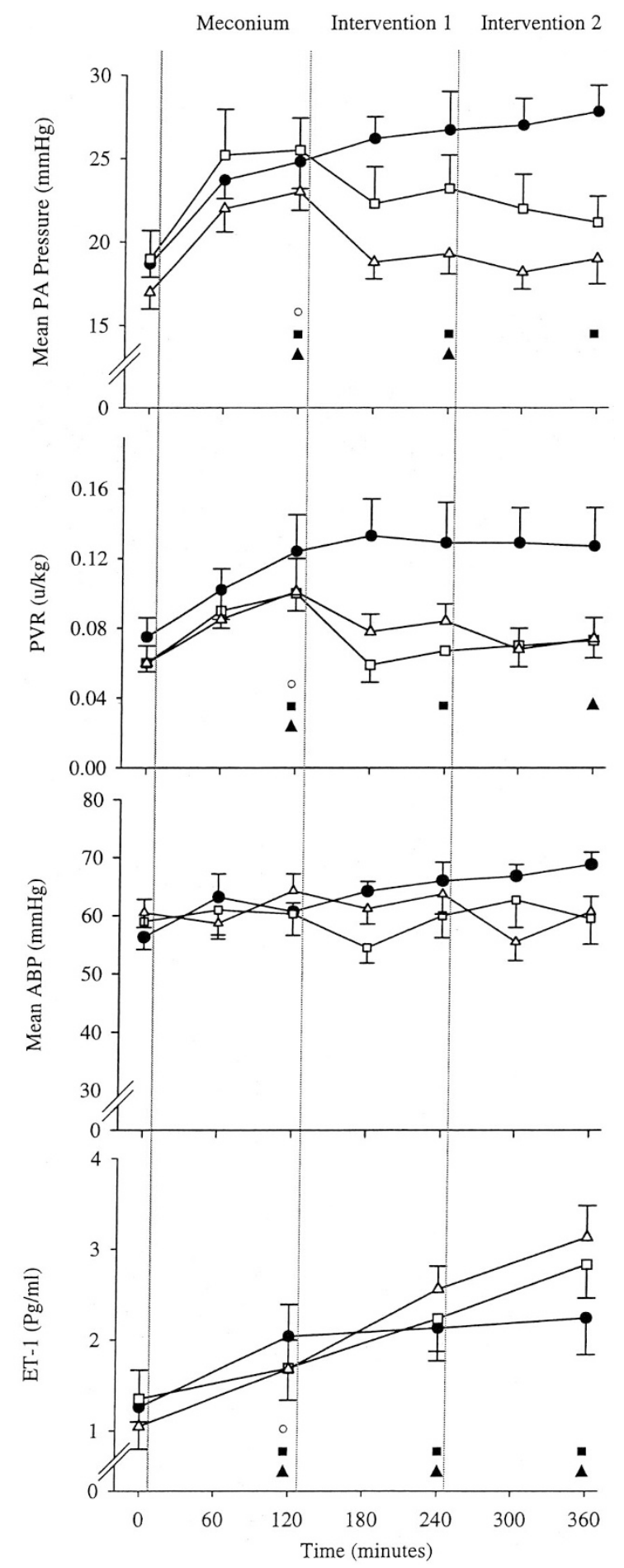

Figure 1. Mean pulmonary artery $(P A)$ pressure, PVR, mean systemic arterial pressure $(A B P)$, and ET-1 levels in controls (closed circle, $n=6$ ); in animals receiving BQ-123 as intervention 1 at 120 min followed by iNO as intervention 2 at $240 \mathrm{~min}$ (open square, $n=6$ ); and in animals receiving iNO as intervention 1 with BQ-123 as intervention 2 (open triangle, $n=6$ ). Significant changes after each intervention are shown as follows: for controls (open circle); for group receiving BQ-123 first (closed square); for group receiving iNO first (closed triangle). Meconium instillation increased mean PA pressure, PVR, and ET-1 significantly in all animals. There were no further significant changes in controls. BQ-123 as intervention 1 lowered PA pressure and PVR, and further reduced PVR as intervention 2. iNO reduced PA pressure when given as intervention 1 , and as intervention 2 , but did not independently lower PVR. ABP fell transiently during the first 60 min after BQ-123, but recovered spontaneously during the next $60 \mathrm{~min}$. ET-1 increased with both interventions. preferred therapy for neonatal pulmonary hypertension (13). Third, we have examined the interaction between the two therapies in this model.

The pulmonary hypertension that followed meconium aspiration was accompanied by an increase in ET-1 levels. In the normal neonate, ET-1 levels are elevated at birth, and have been shown to fall as the elevated PVR of the transitional circulation naturally falls with adaptation to extrauterine life (6) ET levels are further elevated in neonates with persistent pulmonary hypertension when compared with control (6-9).

ET-1 levels in our control group followed a near-identical pattern to PVR. That is, the acute, and significant, elevation over the first $120 \mathrm{~min}$ was followed by a plateau without further significant change. Kuo previously observed a correlation between changes in ET-1 levels and elevation of PVR in a model of meconium aspiration similar to our own (7). The administration of BQ-123 in our study resulted in a further increase in plasma ET-1 despite a fall in PVR. This pattern of response has been demonstrated by others in acute and chronic models of hypoxic pulmonary hypertension $(18,29)$, the proposed mechanism being an increase in "unbound" ET-1 after receptor blockade.

The effect of iNO on ET-1 is more complex. In this study, we have shown a clear rise in ET-1 levels in all animals when given iNO. The rise seen in those first given BQ-123 and then nitric oxide could potentially be interpreted as a "continued" response to the BQ-123 rather than a response to iNO itself. However, the increase in ET-1 in the group first receiving iNO alone would strongly support an independent effect of iNO on ET-1 release.

Our observation of an increase in ET-1 during iNO treatment would agree with some but not all previous investigations. Truog et al. (30) demonstrated a reduction in ET-1 levels during short-term iNO therapy in neonates with PPHN. An insignificant rise in ET-1 was observed by Christou et al. (3) during the first $24 \mathrm{~h}$ of iNO therapy in infants with PPHN. However, in healthy lambs, acutely increased plasma ET-1 levels were observed in response to iNO, lending weight to the suggestion that ET-1 may play a role in the pathophysiology of rebound pulmonary hypertension upon iNO withdrawal (21, 31). Similar findings have been observed in children after surgery for congenital heart disease and adults with acute respiratory distress syndrome (32); and increased lung tissue expression of ET-1 has been demonstrated in a model of lung injury after iNO exposure (33). The exact explanation for an increase in ET-1 during iNO therapy is unclear: proposed mechanisms include nitric oxide-induced alterations in ET-1 gene expression (34), or displacement of the ET-1 from the A receptor in the presence of iNO (35).

The benefits of long-term ET receptor antagonists in the treatment of chronic pulmonary arterial hypertension are becoming increasingly recognized. Recent clinical literature suggests beneficial effects on functional capacity in adults $(36,37)$ and children (38) receiving long-term therapy with the combined oral ET-A and -B receptor antagonist bosentan.

Our current study has important new implications for the clinical treatment of acute pulmonary hypertension. Administration of BQ-123 alone produced relatively greater pulmonary 
Table 2. Hemodynamics and gas exchange during the study period

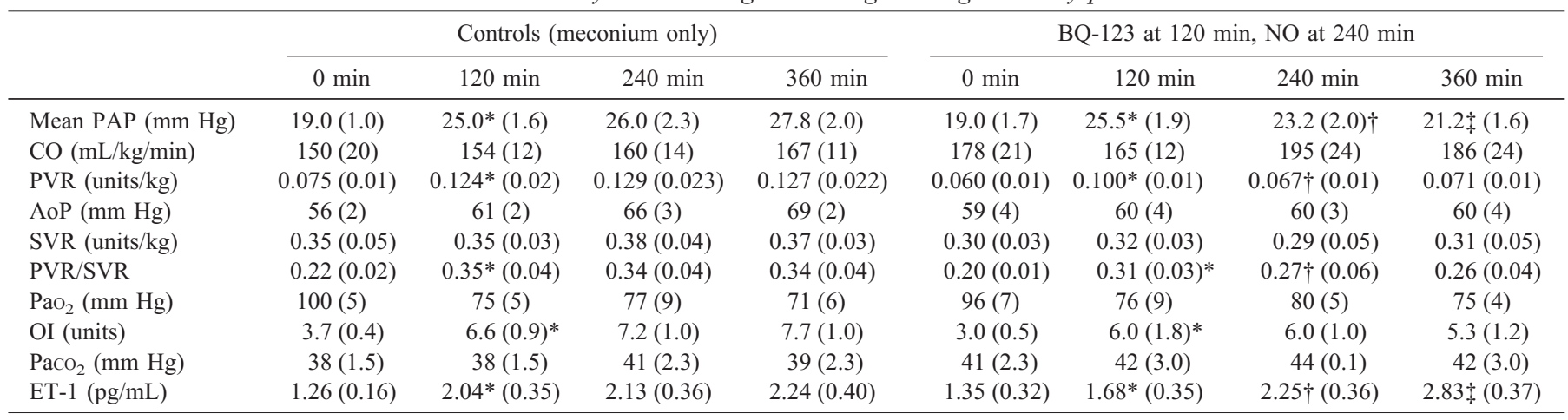

$\mathrm{CO}$, cardiac output; OI, oxygenation index. Within-group statistically significant changes: * $p<0.05,120 \min v s 0 \mathrm{~min} ; \dagger p<0.05$, $240 \mathrm{~min} v s 120 \mathrm{~min}$; $\ddagger p<0.05,360 \mathrm{~min}$ vs $240 \mathrm{~min}$.

Table 2. (Continued)

\begin{tabular}{|c|c|c|c|c|}
\hline & \multicolumn{4}{|c|}{$\mathrm{iNO}$ at $120 \mathrm{~min}, \mathrm{BQ}-123$ at $240 \mathrm{~min}$} \\
\hline & $0 \mathrm{~min}$ & $120 \mathrm{~min}$ & $240 \min$ & $360 \mathrm{~min}$ \\
\hline Mean PAP (mm Hg) & $17.0(1.0)$ & $23.0 *(1.1)$ & $19.3 \dagger(1.2)$ & $19.0(1.5)$ \\
\hline PVR (units/kg) & $0.060(0.00)$ & $0.101 *(0.02)$ & $0.084(0.01)$ & $0.071 \div(0.01)$ \\
\hline $\mathrm{AoP}(\mathrm{mm} \mathrm{Hg})$ & $61(3)$ & $64(3)$ & $64(3)$ & $60(3)$ \\
\hline SVR (units/kg) & $0.34(0.04)$ & $0.31(0.03)$ & $0.32(0.03)$ & $0.30(0.06)$ \\
\hline OI (units) & $2.8(0.4)$ & $5.7(1.4)^{*}$ & $7.1(2.3)$ & $8.4(2.0)$ \\
\hline $\mathrm{PaCO}_{2}(\mathrm{~mm} \mathrm{Hg})$ & $38(1.5)$ & $39(2.3)$ & $43(1.0)$ & $41(1.5)$ \\
\hline $\mathrm{ET}-1(\mathrm{pg} / \mathrm{mL})$ & $1.05(0.25)$ & $1.78 *(0.32)$ & $2.56 \div(0.25)$ & $3.13 \div(0.35)$ \\
\hline
\end{tabular}

$\mathrm{CO}$, cardiac output; OI, oxygenation index. Within-group statistically significant changes: ${ }^{*} p<0.05,120 \mathrm{~min} v s 0 \mathrm{~min} ; \dagger p<0.05,240 \mathrm{~min} v s 120 \mathrm{~min}$; $\pm p<0.05,360$ min vs 240 min.

vasodilatation than did iNO alone, with minimal systemic side effects, and without any deterioration in oxygenation. BQ-123 tended to increase cardiac output, and, when given in addition to iNO, resulted in a slight but further reduction in PVR. ET-A receptor blockade may well have a role in the treatment of PPHN secondary to meconium aspiration syndrome, and potentially from other aetiologies.

Limitations. There are a few potential limitations within our study. First, our choice of the dose of BQ-123 $(1 \mathrm{mg} / \mathrm{kg})$ was based upon the doses used in earlier animal studies $(39,40)$. Second, the animals studied were about 2 wk old, and thus may have different, or less exaggerated, hemodynamic responses than piglets in the first hours of life. No animal had an intracardiac shunt, which could potentially influence (or limit) any acute effect of an intravenous pulmonary vasodilator upon oxygenation. However, a number of previous investigations of pulmonary vasodilators in models of acute pulmonary hypertension $(27,29,41)$ and, specifically, therapies for meconium aspiration syndrome $(42,43)$ have been explored in more mature animals. Indeed, having demonstrated an acute rise in ET-1 levels coincident with an increase in PVR after meconium aspiration, it would seem appropriate to investigate the subsequent actions of an ET-A receptor antagonist in our model.

\section{CONCLUSION}

The selective ET-A receptor antagonist, BQ-123, is a highly effective pulmonary vasodilator in this model of acute pulmo- nary hypertension secondary to meconium aspiration syndrome. BQ-123 did not produce any sustained systemic side effects and did not impair oxygenation. When given to subjects already receiving nitric oxide, BQ-123 resulted in a subtle additional reduction in PVR. Targeting the pulmonary endothelium using ET-A receptor antagonists may represent a safe alternative or adjunctive therapeutic approach in the acute management of persistent pulmonary hypertension of the newborn.

\section{REFERENCES}

1. Kinsella JP, Abman SH 1995 Recent developments in the pathophysiology and treatment of persistent pulmonary hypertension of the newborn. J Pediatr 126:853864

2. Coltart TM, Byrne DL, Bates SA 1989 Meconium aspiration syndrome: a 6-year retrospective study. Br J Obstet Gynaecol 96:411-414

3. Christou H, Adatia I, Van Marter LJ, Kane JW, Thompson JE, Stark AR, Wessel DL, Kourembanas S 1997 Effect of inhaled nitric oxide on endothelin-1 and cyclic guanosine 5'-monophosphate plasma concentrations in newborn infants with persistent pulmonary hypertension. J Pediatr 130:603-611

4. Yanagisawa M, Kurihara H, Kimura S, Tomobe Y, Kobayashi M, Mitsui Y, Yazaki Y, Goto K, Masaki T 1988 A novel potent vasoconstrictor peptide produced by vascular endothelial cells. Nature 332:411-415

5. Ivy DD, Kinsella JP, Abman SH 1994 Physiologic characterization of endothelin A and $\mathrm{B}$ receptor activity in the ovine fetal pulmonary circulation. $\mathrm{J}$ Clin Invest 93:2141-2148

6. Malamitsi-Puchner A, Economou E, Sevastiadou S, Efstathopoulos T, Nicolopoulos D 1993 Endothelin 1-21 plasma levels on the first and fourth postpartum day in normal full-term neonates. Dev Pharmacol Ther 20:195-198

7. Kuo C, Chen J 1999 Effect of meconium aspiration on plasma endothelin-1 level and pulmonary hemodynamics in a piglet model. Biol Neonate 76:228-234

8. Rosenberg AA, Kennaugh J, Koppenhafer SL, Loomis M, Chatfield BA, Abman SH 1993 Elevated immunoreactive endothelin-1 levels in newborn infants with persistent pulmonary hypertension. J Pediatr 123:109-114 
9. Kumar P, Kazzi NJ, Shankaran S 1996 Plasma immunoreactive endothelin-1 concentrations in infants with persistent pulmonary hypertension of the newborn. Am J Perinatol 13:335-341

10. Ishikawa S, Miyauchi T, Sakai S, Ushinohama H, Sagawa K, Fusazaki N, Kado H, Sunagawa H, Honda S, Ueno H, Yamaguchi I, Sugishita Y, Goto K 1995 Elevated levels of plasma endothelin-1 in young patients with pulmonary hypertension caused by congenital heart disease are decreased after successful surgical repair. J Thorac Cardiovasc Surg 110:271-273

11. Cody RJ, Haas GJ, Binkley PF, Capers Q, Kelley R 1992 Plasma endothelin correlates with the extent of pulmonary hypertension in patients with chronic congestive heart failure. Circulation 85:504-509

12. Pousset F, Isnard R, Lechat $P$, Kalotka H, Carayon A, Maistre G, Escolano S, Thomas D, Komajda M 1997 Prognostic value of plasma endothelin-1 in patients with chronic heart failure. Eur Heart J 18:254-258

13. Clark RH, Kueser TJ, Walker MW, Southgate WM, Huckaby JL, Perez JA, Roy BJ, Keszler M, Kinsella JP 2000 Low-dose nitric oxide therapy for persistent pulmonary hypertension of the newborn. Clinical Inhaled Nitric Oxide Research Group. N Engl J Med 342:469-474

14. Mercier JC, Lacaze T, Storme L, Roze JC, Dinh-Xuan AT, Dehan M 1998 Diseaserelated response to inhaled nitric oxide in newborns with severe hypoxaemic respiratory failure. French Paediatric Study Group of Inhaled NO. Eur J Pediatr 157:747752

15. Schulze-Neick I, Li J, Reader JA, Shekerdemian L, Redington AN, Penny DJ 2002 The endothelin antagonist BQ123 reduces pulmonary vascular resistance after surgical intervention for congenital heart disease. J Thorac Cardiovasc Surg 124:435-441

16. Coe Y, Haleen SJ, Welch KM, Liu YA, Coceani F 2002 The endothelin A receptor antagonists PD 156707 (CI-1020) and PD 180988 (CI-1034) reverse the hypoxic pulmonary vasoconstriction in the perinatal lamb. J Pharmacol Exp Ther 302:672680

17. Coe Y, Haleen SJ, Welch KM, Coceani F 2000 The endothelin-A-receptor antagonis PD 180988 (CI-1034) selectively reverses the pulmonary vasoconstrictor response to hypoxia in the lamb. J Cardiovasc Pharmacol 36:S331-333

18. Perreault T, Berkenbosch JW, Barrington KJ, Decker ER, Wu C, Brock TA, Baribeau J 2001 TBC3711, an ET(A) receptor antagonist, reduces neonatal hypoxia-induced pulmonary hypertension in piglets. Pediatr Res 50:374-383

19. Thebaud B, de Lagausie P, Forgues D, Aigrain Y, Mercier JC, Dinh-Xuan AT 2000 ET(A)-receptor blockade and ET(B)-receptor stimulation in experimental congenita diaphragmatic hernia. Am J Physiol Lung Cell Mol Physiol 278:L923-L932

20. Prie S, Stewart DJ, Dupuis J 1998 EndothelinA receptor blockade improves nitric oxide-mediated vasodilation in monocrotaline-induced pulmonary hypertension. Circulation 97:2169-2174

21. Wedgwood S, McMullan DM, Bekker JM, Fineman JR, Black SM 2001 Role for endothelin-1-induced superoxide and peroxynitrite production in rebound pulmonary hypertension associated with inhaled nitric oxide therapy. Circ Res 89:357-364

22. Shekerdemian LS, Ravn HB, Penny DJ 2002 Intravenous sildenafil lowers pulmonary vascular resistance in a model of neonatal pulmonary hypertension. Am J Respir Crit Care Med 165:1098-1102

23. Channick RN, Rubin LJ 2001 New and experimental therapies for pulmonary hypertension. Clin Chest Med 22:539-545

24. Higenbottam TW, Laude EA 1998 Endothelial dysfunction providing the basis for the treatment of pulmonary hypertension: Giles F. Filley lecture. Chest 114:72S-79S

25. Oparil S, Chen SJ, Meng QC, Elton TS, Yano M, Chen YF 1995 Endothelin-A receptor antagonist prevents acute hypoxia-induced pulmonary hypertension in the rat. Am J Physiol 268:L95-L100
26. Kuo CY 2001 Endothelin-A receptor antagonist prevents neonatal pulmonary hypertension in meconium aspiration in piglets. J Formos Med Assoc 100:420-423

27. Holm P, Liska J, Franco-Cereceda A 1998 The ETA receptor antagonist, BMS 182874 , reduces acute hypoxic pulmonary hypertension in pigs in vivo. Cardiovasc Res 37:765-771

28. Wang L, Zhu du M, Su X, Bai CX, Ware LB, Matthay MA 2004 Acute cardiopulmonary effects of a dual-endothelin receptor antagonist on oleic acid-induced pulmonary arterial hypertension in dogs. Exp Lung Res 30:31-42

29. Ambalavanan N, Philips JB, 3rd, Bulger A, Oparil S, Chen YF 2002 Endothelin-A receptor blockade in porcine pulmonary hypertension. Pediatr Res 52:913-921

30. Truog WE, Pallotto E, Clark P, Banks B, Kaftan HA, Ekekezie II, Norberg M, Ballard RA 2002 Interaction of endogenous endothelin-1 and inhaled nitric oxide in term and preterm infants. Clin Sci (Lond) 103:294S-297S

31. McMullan DM, Bekker JM, Johengen MJ, Hendricks-Munoz K, Gerrets R, Black SM, Fineman JR 2001 Inhaled nitric oxide-induced rebound pulmonary hypertension: role for endothelin-1. Am J Physiol Heart Circ Physiol. 280:H777-H785

32. Pearl JM, Nelson DP, Raake JL, Manning PB, Schwartz SM, Koons L, Shanley TP, Wong HR, Duffy JY 2002 Inhaled nitric oxide increases endothelin-1 levels: a potential cause of rebound pulmonary hypertension. Crit Care Med 30:89-93

33. Chen L, He H, Fernandez Mondejar E, Freden F, Wiklund P, Alving K, Hedenstierna G 2001 Endothelin-1 and nitric oxide synthase in short rebound reaction to short exposure to inhaled nitric oxide. Am J Physiol Heart Circ Physiol. 281:H124-H131

34. Junbao D, Jianfeng J, Wanzhen L, Bin Z, Heping Z 1999 Nitric oxide impacts endothelin-1 gene expression in intrapulmonary arteries of chronically hypoxic rats. Angiology 50:479-485

35. Goligorsky MS, Tsukahara H, Magazine H, Andersen TT, Malik AB, Bahou WF 1994 Termination of endothelin signaling: role of nitric oxide. J Cell Physio 158:485-494

36. Rubin LJ, Badesch DB, Barst RJ, Galie N, Black CM, Keogh A, Pulido T, Frost A, Roux S, Leconte I, Landzberg M, Simonneau G 2002 Bosentan therapy for pulmonary arterial hypertension. N Engl J Med 346:896-903

37. Channick RN, Simonneau G, Sitbon O, Robbins IM, Frost A, Tapson VF, Badesch DB, Roux S, Rainisio M, Bodin F, Rubin LJ 2001 Effects of the dual endothelinreceptor antagonist bosentan in patients with pulmonary hypertension: a randomised placebo-controlled study. Lancet 358:1119-1123

38. Barst RJ, Ivy D, Dingemanse J, Widlitz A, Schmitt K, Doran A, Bingaman D, Nguyen N, Gaitonde M, van Giersbergen PL 2003 Pharmacokinetics, safety, and efficacy of bosentan in pediatric patients with pulmonary arterial hypertension. Clin Pharmacol Ther 73:372-382

39. Cirino M, Martin E, Yano M, Rodger IW 1997 Cardiovascular and renal actions of the endothelin(B) receptor in pigs. J Cardiovasc Pharmacol 29:704-712

40. Fineman JR, Wong J, Mikhailov T, Vanderford PA, Jerome HE, Soifer SJ 1999 Altered endothelial function in lambs with pulmonary hypertension and acute lung injury. Pediatr Pulmonol 27:147-156

41. Ichinose F, Erana-Garcia J, Hromi J, Raveh Y, Jones R, Krim L, Clark MW, Winkle JD, Bloch KD, Zapol WM 2001 Nebulized sildenafil is a selective pulmonary vasodilator in lambs with acute pulmonary hypertension. Crit Care Med 29:10001005

42. Chappell SE, Wolfson MR, Shaffer TH 2001 A comparison of surfactant delivery with conventional mechanical ventilation and partial liquid ventilation in meconium aspiration injury. Respir Med 95:612-617

43. Hachey WE, Eyal FG, Curtet-Eyal NL, Kellum FE 1998 High-frequency oscillatory ventilation versus conventional ventilation in a piglet model of early meconium aspiration. Crit Care Med 26:556-561 